\title{
IMPLEMENTASI DAN PENGUJIAN ANTARMUKA SISTEM INFORMASI PENANGGULANGAN KEMISKINAN DI KABUPATEN OGAN KOMERING ILIR
}

\author{
Usman Ependi \\ Program Studi Teknik Informatika, Fakultas Ilmu Komputer, Universitas Bina Darma \\ Jl Ahmad Yani No 12 Plaju, Palembang, 30264 \\ Telp: (0711) 515679, Fax: (0711) 515582 \\ E-mail: usman@mail.binadarma.ac.id
}

\begin{abstract}
The information system is now used in every field of life i.e. in education, industrial (business) and government. Information system can be implemented based on the needs of an organization either to solve problems or to improve the quality of service. In this research, the information system implemented in the field of governance is the information systems poverty reduction (Simpeke) in Ogan Komering Ilir Regency. The implementation of Simpeke in Ogan Komering Ilir Regency was conducted to provide information related to the condition of the residents to support the government in making the policy. Simpeke can display information about residents' predicate based on economic level, whether they are prosperous, middle, near-poor, poor and very poor. By having these kinds of data, the Ogan Komering Ilir regency can make a well-targeted poverty reduction policies in accordance with the needs of the community. Simpeke itself has done implemented an alpha and beta testing using a black box testing approach. From the test results, it can be concluded that 51\% of Simpeke information system end users agree with the implementation of Simpeke. It means that Simpeke can assist the goverment in making poverty reduction policies.
\end{abstract}

\section{Abstrak}

Sistem informasi saat ini telah digunakan disetiap bidang kehidupan baik pendidikan, industri (usaha) dan pemerintahan. Sistem informasi dapat diimplementasikan berdasarkan pada kebutuhan sebuah organisasi baik dikarenakan untuk menyelesaikan masalah ataupun untuk meningkatkan kualitas pelayanan. Salah satu sistem informasi yang diimplementasi pada dunia pemerintahan adalah sistem informasi penanggulangan kemiskinan (Simpeke) pada Kabupaten Ogan Komering Ilir. Implementasi Simpeke pada Kabupaten Ogan Komering Ilir dilakukan untuk menyajikan informasi berkaitan dengan penduduk yang digunakan untuk mendukung pemerintah dalam membuat kebijakan. Dikarenakan Simpeke dapat menampilkan informasi penduduk berdasarkan predikat penduduk dengan tingkatan ekonomi seperti sejahtera, menengah, hampir miskin, miskin dan sangat miskin. sehingga pemerintah Kabupaten Ogan Komering Ilir dengan tersedianya data tersebut dapat membuat kebijakan pengentasan kemiskinan tepat sasaran dan sesuai dengan kebutuhan masyarakat. Simpeke sendiri diimplementasikan dan dilakukan pengujian alpha dan beta dengan menggunakan pendekatan black box testing. Dari hasil pengujian dapat disimpulkan bahwa sebanyak $51 \%$ pengguna akhir dari sistem informasi penanggulangan kemiskinan (Simpeke) Kabupaten OKI menyatakan sangat setuju dengan impelementasi Simpeke yang berarti simpeke dapat membantu dalam membuat kebijakan pengentasan kemiskinan.

Kata kunci: Pengujian Antarmuka, Simpeke, Black Box Testing

\section{PENDAHULUAN}

Sistem informasi saat ini telah digunakan disetiap bidang kehidupan baik pendidikan, industri (usaha) dan pemerintahan. Penggunaan sistem informasi pada dunia pendidikan seperti penggunaan e-learning, e-library dan e-book, penggunaan sistem informasi pada industri (usaha) seperti penggunaan e-commernce, $e$ payment dan $e$-ticketing, sedangkan penggunaan sistem informasi pada dunia pemerintahan antara lain adalah e-planning dan e-procurement. Jika dilihat dari jenis nya sistem informasi memiliki delapan (8) jenis yaitu transaction processing systems (TPS). office automation systems (OAS), knowledge work systems (KWS), management information system (MIS), decision support systems (DSS), expert system, group decision support systems (GDSS), computer support collaborative work systems (CSCW) dan executive support systems (ESS) (Ependi 2012). Dari jenis sistem informasi tersebut dapat dikatakan bahwa penggunaan sistem informasi 
sudah mencakup segala bidang kehidupan. Penggunaan sistem informasi dikarenakan sistem informasi merupakan suatu kumpulan dari komponen-komponen dalam suatu organisasi yang berhubungan dengan proses penciptaan dan pengaliran informasi (Indrajit 2001). Sehingga dengan adanya sistem informasi sebuah organisasi dapat menciptakan dan menyajikan informasi yang akurat sesuai dengan kebutuhan.

Sistem informasi dapat diimplementasikan berdasarkan pada kebutuhan sebuah organisasi baik dikarenakan untuk menyelesaikan masalah ataupun untuk meningkatkan kualitas layanan organisasi. Salah satu sistem informasi dapat diimplementasi adalah sistem informasi penanggulangan kemiskinan (Simpeke) Kabupaten Ogan Komering Ilir. Implementasi Simpeke pada Kabupaten Ogan Komering Ilir tersebut dilakukan untuk menyajikan informasi berkaitan dengan penduduk yang digunakan untuk mendukung pemerintah dalam membuat kebijakan. Simpeke juga menampilkan informasi penduduk berdasarkan predikat penduduk dengan tingkatan ekonomi seperti sejahtera, menengah, hampir miskin, miskin dan sangat miskin. sehingga pemerintah Kabupaten Ogan Komering Ilir dapat membuat kebijakan pengentasan kemiskinan tepat sasaran dan sesuai dengan kebutuhan masyarakat. Selain itu juga implementasi Simpeke memiliki resiko yang rendah dengan tingkat ancaman pada level negligible, baik dari sisi pelaksanaannya maupun sistem informasi itu sendiri. Simpeke hanya menampilkan informasi dan data kemiskinan disetiap kecamatan (Rahadi 2010).

\section{METODOLOGI}

Dalam penelitan ini metodologi penelitian yang digunakan adalah metode penelitian deskriptif dan metode pengujian alpha dan beta. Metode penelitian yang digunakan pada penelitian ini adalah metode deskriptif. Metode penelitian deskriptif adalah salah satu metode yang banyak digunakan pada penelitian dengan tujuan untuk menjelaskan suatu kejadian. penelitian desktiptif adalah sebuah penelitian yang bertujuan untuk memberikan atau menjabarkan suatu keadaan atau fenomena yang terjadi saat ini dengan menggunakan prosedur ilmiah untuk menjawab masalah secara aktual (Sugiyono 2011). Menurut pendapat lain metode deskripsi adalah sebuah metode yang berusaha mendeskripsikan, menginterpretasikan sesuatu, misalnya kondisi atau hubungan yang ada, pendapat yang berkembang, proses yang sedang berlangsung, akibat atau efek yang terjadi atau tentang kecenderungan yang sedang berlangsung (Sukmadinata 2006). Dari dua pendapat tersebut dapat dikatakan bahwa penelitian ini menjelaskan atau menjabarkan suatu keadaan atau menginterpretasikan sesuatu, misalnya kondisi atau hubungan yang ada.

Sistem informasi penanggulangan kemiskinan (Simpeke) Kabupaten Ogan Komering Ilir dilakukan pengujian sebanyak dua tahapan. Tahapan pertama pengujian alpha dan kedua pengujian beta. Pengujian alpha dilakukan untuk mengetahui fungsional dari sistem informasi penanggulangan kemiskinan berdasarkan rencana pengujian dengan menggunakan pendekatan black box testing. Rencana pengujian alpha dengan pendekatan black box testing terlihat pada tabel 1 .

Sedangkan pengujian beta sistem informasi penanggulangan kemiskinan Kabupaten Ogan Komering Ilir dilakukan dengan cara pengujian langsung terhadap pengguna akhir dari sistem informasi, dimana pengguna akhir menggunakan secara langsung sistem informasi tanpa dilakukan pengawasan oleh pengembang. Selanjutnya pengguna akhir sistem informasi diminta untuk mengisi pertanyaan pada kuersioner berkaitan dengan sistem informasi yang mereka gunakan.

\section{HASIL DAN PEMBAHASAN}

Hasil dari implementasi yang telah dilakukan berupada sistem informasi penanggulangan kemiskinan dengan ilustrasi struktur antarmuka terlihat pada gambar 1

Tabel 1. Rencana pengujian alpha

\begin{tabular}{lll}
\hline \multicolumn{1}{c}{ Menu yang diuji } & \multicolumn{1}{c}{ Detail Pengujian } & $\begin{array}{c}\text { Jenis } \\
\text { Pengujian }\end{array}$ \\
\hline Login & Pengguna dengan level administrator & Black box \\
\hline Import \& Export data & Import dan Export data rumah tangga dan keterangan pokok & Black box \\
\hline Rumah tangga & Input, edit dan delete data rumah tangga & Black box \\
\hline Indikator kemiskinan & Input, edit dan delete data indikator kemiskinan rumah tangga & Black box \\
\hline Keterangan pokok & $\begin{array}{l}\text { Input, edit dan delete } \text { predikat penduduk berdasarkan indikator } \\
\text { keterangan pokok }\end{array}$ & Black box \\
\hline
\end{tabular}




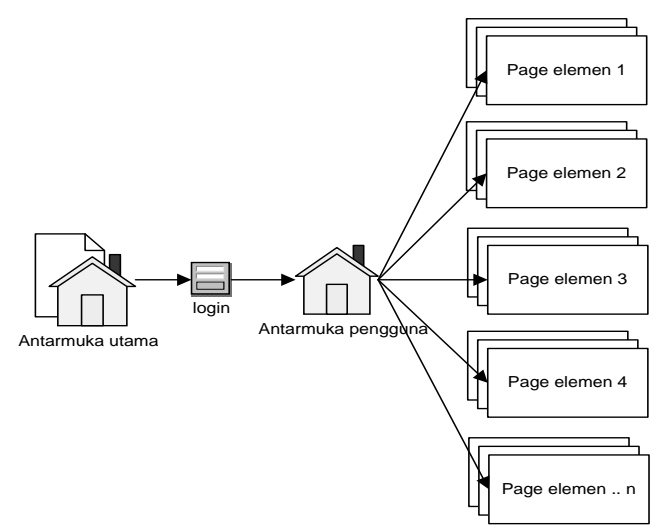

Gambar 1. Ilustrasi Antarmuka Simpeke

\subsection{Hasil Implementasi Antarmuka}

Hasil implementasi antarmuka sistem informasi penanggulangan kemiskinan Kabupaten Ogan Komering Ilir dapat dilihat pada gambar 2 . Antarmuka pada gambar 2 merupakan antarmuka utama dari simpeke, dari antarmuka utama tersebut pengguna dapat melakukan login dan kemudian mengelola data penduduk berdasarkan indikator kemiskinan.

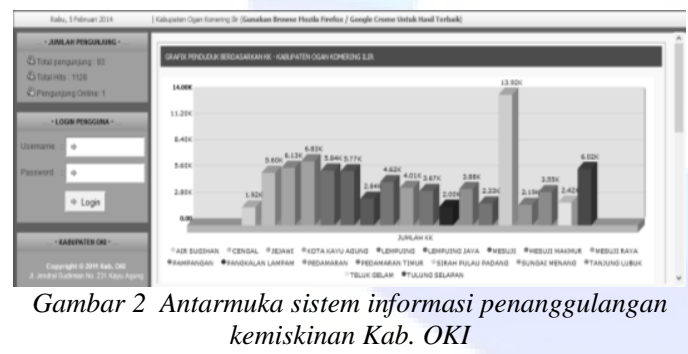

Pada antarmuka sistem informasi yang terlihat pada gambar 1 jika pengguna melakukan login dengan benar maka secara otomatis akan menampilkan antarmuka administrator sistem informasi penanggulangan kemiskinan. Tampilan antarmuka administrator tersebut dapat dilihat pada gambar 3 .

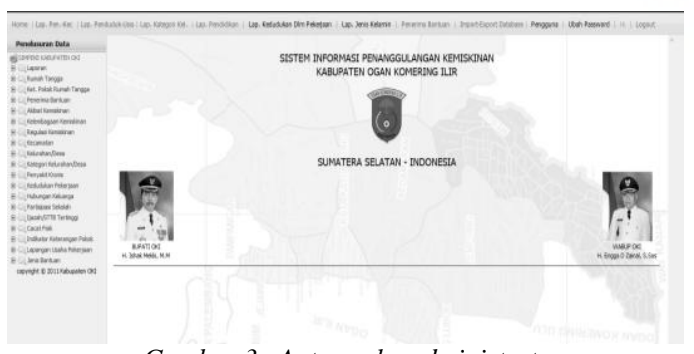

Gambar 3. Antarmuka administrator

Proses yang dapat dilakukan pada antarmuka administrator antara lain import \& export data, kelola data rumah tangga, kelola indikator kemiskinan, kelola keterangan pokok rumah tangga, laporan kedudukan dalam pekerjaan, laporan predikat penduduk, laporan berdasarkan indikator kemiskinan, laporan penduduk

berdasarkan kategori kelurahan/desa dan laporan penduduk berdasarkan pendidikan. Namun proses utama dari sistem informasi penanggulangan kemiskinan ini terdapat tiga fase utama. Yang pertama proses memasukkan data penduduk atau yang dikenal dengan rumah tangga dan anggota rumah tangga. Proses ini dapat dilihat pada gambar 4 .

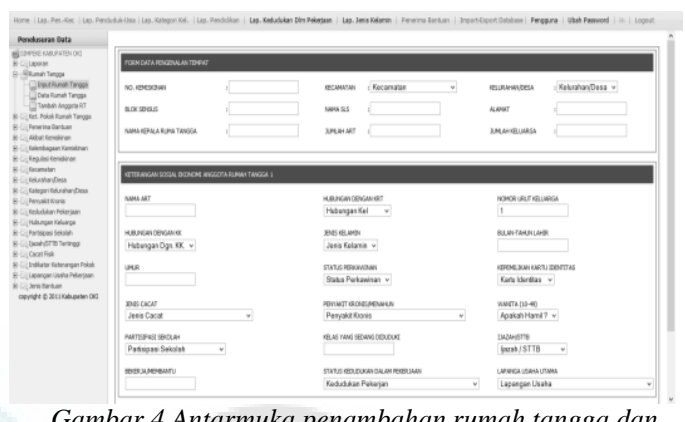

Gambar 4 Antarmuka penambahan rumah tangga dan anggota rumah tangga

Setelah penambahan data rumah tangga dan anggota rumah tangga dilakukan maka proses selanjutnya adalah penambahan indikator kemiskinan. Indikator kemiskinan adalah daftar indikator yang nantinya digunakan untuk menentukan status atau predikat penduduk yang ada. Pada gambar 5 terlihat antarmuka dari proses input dari indikator kemiskinan.

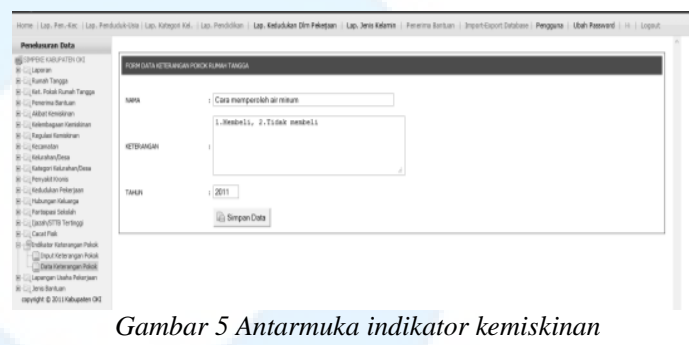

Tahapan berikutnya setelah proses peng-input-an data rumah tangga dan data indikator kemiskinan adalah tahap penentuan predikat penduduk berdasarkan tingkatan ekonomi seperti sejahtera, menengah, hampir miskin, miskin dan sangat miskin. Penentuan predikat tersebut dilakukan pada proses penginputan keterangan pokok rumah tangga yang terlihat pada gambar 6 .

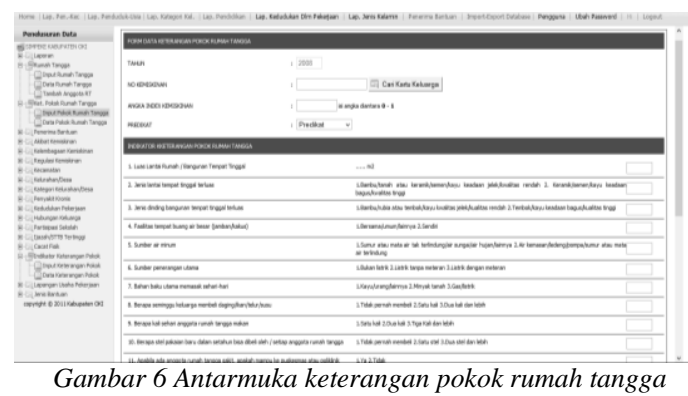


Jika proses penginputan data keterangan pokok rumah tangga selesai dilakukan, maka selanjutnya baru dapat dilihat data predikat penduduk berdasarkan tingkatan ekonomi seperti sejahtera, menengah, hampir miskin, miskin dan sangat miskin. Data tersebut dapat menjadi acuan untuk menentukan arah kebijakan pengentasan kemiskinan di Kabupaten Ogan Komering Ilir. Data predikat penduduk tersebut ditampilkan secara rinci baik berdasarkan kecamatan atau kelurahan/desa. Sehingga dapat terlihat jelas daerah yang berpenduduk hampir miskin, miskin dan sangat miskin. Antarmuka predikat penduduk dilihat dari tingkatan ekonomi terlihat pada gambar 6.

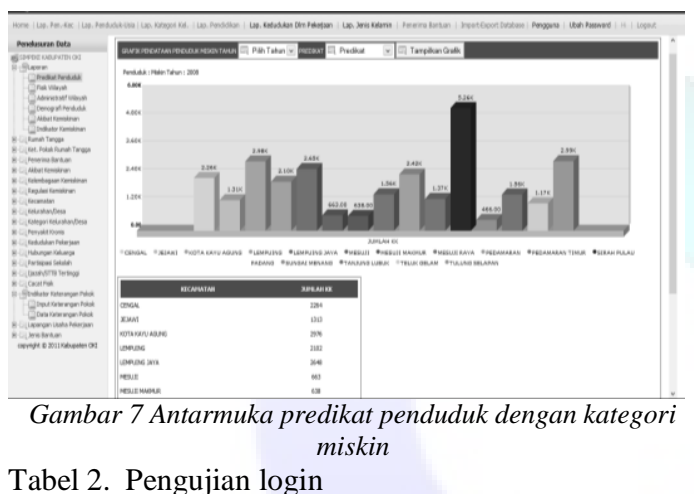

Selain data predikat penduduk juga dapat dilihat data rumah tangga (penduduk) berdasarkan indikator kemiskinan. Karena kedua data tersebut didapat setelah proses penginputan data keterangan pokok rumah tangga. Data penduduk dilihat dari indikator kemiskinan dapat dilihat pada gambar 7 .

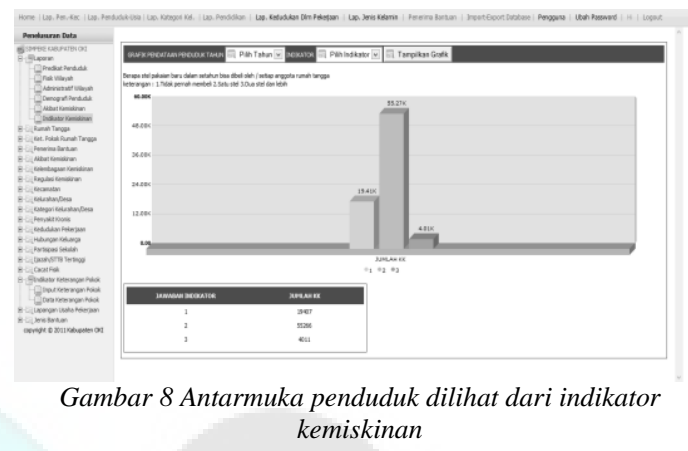

\subsection{Hasil Pengujian Alpha}

Hasil pengujian yang dilakukan berdasarkan rencana pengujian yang telah ditetapkan dapat dilihat pada tabel 2 sampai tabel 16.

\section{Kasus dan Hasil Ujicoba (Data Benar)}

\begin{tabular}{ll}
\hline $\begin{array}{l}\text { Data } \\
\text { masukan }\end{array}$ & $\begin{array}{l}\text { Username : usman } \\
\text { Password : ependi }\end{array}$ \\
\hline $\begin{array}{l}\text { Yang } \\
\text { diharapkan }\end{array}$ & $\begin{array}{l}\text { Setelah mengisi username dan password yang benar kemudian klik button login maka } \\
\text { akan menampilkan halaman utama administrator simpeke }\end{array}$ \\
\hline Pengamatan & $\begin{array}{l}\text { Username dan password yang dimasukan dapat diterima dan button login berfungsi } \\
\text { dengan baik dan dapat menampilkan halaman administrator simpeke }\end{array}$ \\
\hline Kesimpulan & {$[\checkmark]$ Diterima [ ] Ditolak } \\
\hline \multicolumn{1}{c}{ Kasus dan Hasil Ujicoba (Data Salah) } \\
masukan & $\begin{array}{l}\text { Username : usman } \\
\text { Password : passalah }\end{array}$ \\
\hline $\begin{array}{l}\text { Yang } \\
\text { diharapkan }\end{array}$ & $\begin{array}{l}\text { Setelah mengisi username dan password maka menekan button login, kemudian } \\
\text { menampilkan pesan bahwa username atau password yang dimasukan salah, silahkan } \\
\text { masukan } \text { username dan password yang bernar }\end{array}$ \\
\hline Pengamatan & $\begin{array}{l}\text { Setelah memasukan username dan password yang tidak sesuai tidak menampilkan } \\
\text { pesan kesalahan seerti yang diharapkan }\end{array}$ \\
\hline Kesimpulan & {$[$ ] Diterima [ $\checkmark$ ] Ditolak } \\
\hline
\end{tabular}

Tabel 3. Pengujian import-export data rumah tangga

\begin{tabular}{|c|c|}
\hline \multicolumn{2}{|r|}{ Kasus dan Hasil Ujicoba (Data Benar) } \\
\hline Data masukan & File data rumah tangga $*$.csv dengan format yang sesuai \\
\hline Yang diharapkan & $\begin{array}{l}\text { Setelah data file rumah tangga *.csv ditambahkan dan kermudian button proses } \\
\text { data diklik maka proses extract data ke database dilakukan, kemudian } \\
\text { menampilkan proses berhasil dilakukan }\end{array}$ \\
\hline Pengamatan & $\begin{array}{l}\text { Data rumah tangga *.csv dimasukan dan proses data, sistem dapat menampilkan } \\
\text { pesan data berhasil diproses ke database. }\end{array}$ \\
\hline Kesimpulan & {$[\checkmark]$ Diterima [ ] Ditolak } \\
\hline \multicolumn{2}{|r|}{ Kasus dan Hasil Ujicoba (Data Salah) } \\
\hline Data masukan & File data rumah tangga $*$ fileextention dengan format yang tidak sesuai \\
\hline Yang diharapkan & $\begin{array}{l}\text { Data rumah tangga *fileextention dimasukan dan proses data dilakukan } \\
\text { menampilkan data tidak valid dan proses dibatalkan }\end{array}$ \\
\hline
\end{tabular}


Ependi, Implementasi dan Pengujian Antarmuka Sistem Informasi Penanggulangan Kemiskinan..

\begin{tabular}{ll}
\hline Pengamatan & proses data dilakukan menampilkan data tidak valid dan proses dibatalkan \\
\hline Kesimpulan & {$[\checkmark]$ Diterima [ ] Ditolak } \\
\hline
\end{tabular}

Tabel 4. Pengujian data rumah tangga

\begin{tabular}{|c|c|}
\hline \multicolumn{2}{|r|}{ Kasus dan Hasil Ujicoba (Data Benar) } \\
\hline \multicolumn{2}{|c|}{ a. Input data rumah tangga } \\
\hline Data masukan & $\begin{array}{l}\text { Memasukan data rumah tangga dan anggota rumah tangga sesuai dengan field yang } \\
\text { disediakan nomor kemiskinan }\end{array}$ \\
\hline Yang diharapkan & $\begin{array}{l}\text { Proses masukan data rumah tangga dan anggota rumah tangga dilakukan. Klik } \\
\text { button simpan data, data disimpan ke database dan menampilkan form masukan } \\
\text { rumah tangga kembali }\end{array}$ \\
\hline Pengamatan & $\begin{array}{l}\text { Data rumah tangga dan anggota rumah tangga berhasil dimasukan ke database dan } \\
\text { menampilkan form, sesuai dengan yang diharapkan }\end{array}$ \\
\hline Kesimpulan & {$[\checkmark]$ Diterima [ ] Ditolak } \\
\hline \multicolumn{2}{|c|}{ b. Edit data rumah tangga } \\
\hline Data masukan & $\begin{array}{l}\text { Memilih kecamatan dan kelurahan/desa dan menampilkan data rumah tangga dan } \\
\text { nomor kemiskinan }\end{array}$ \\
\hline Yang diharapkan & $\begin{array}{l}\text { Menampilkan data rumah tangga berdasarkan kecamatan dan kelurahan/desa, klik } \\
\text { link edit, maka form data edit ditampilkan, kemudian proses disimpan dan } \\
\text { menampilkan edit sukses dilakukan }\end{array}$ \\
\hline Pengamatan & Data rumah tangga dapat ditampilkan dan menampilkan $e$ dit sukses dilakukan \\
\hline Kesimpulan & {$[\checkmark]$ Diterima [ ] Ditolak } \\
\hline \multicolumn{2}{|c|}{ c. Delete data rumah tangga } \\
\hline Data masukan & $\begin{array}{l}\text { Memilih kecamatan dan kelurahan/desa dan menampilkan data rumah tangga dan } \\
\text { nomor kemiskinan }\end{array}$ \\
\hline Yang diharapkan & $\begin{array}{l}\text { Menampilkan data rumah tangga berdasarkan kecamatan dan kelurahan/desa, klik } \\
\text { link delete, menampilkan pesan konfirmasi hapus, jika ya maka data terhapus }\end{array}$ \\
\hline Pengamatan & Menampilkan pesan konfirmasi hapus dan data terhapus \\
\hline Kesimpulan & {$[\checkmark]$ Diterima [ ] Ditolak } \\
\hline \multicolumn{2}{|r|}{ Kasus dan Hasil Ujicoba (Data Salah) } \\
\hline \multicolumn{2}{|c|}{ a.Input data rumah tangga } \\
\hline Data masukan & Nomor Kemiskinan yang sama \\
\hline Yang diharapkan & Menampilkan pesan kesalahan Nomor Kemiskinan telah ada \\
\hline Pengamatan & Dapat menampilkan pesan kesalahan nomor kemiskinan telah ada \\
\hline Kesimpulan & {$[\checkmark]$ Diterima [ ] Ditolak } \\
\hline \multicolumn{2}{|c|}{ b.Edit data rumah tangga } \\
\hline Data masukan & Nomor Kemisknan yang salah \\
\hline Yang diharapkan & Tidak dapat menampilkan data pada form edit \\
\hline Pengamatan & Data tidak tampil pada form edit \\
\hline Kesimpulan & {$[\checkmark]$ Diterima [ ] Ditolak } \\
\hline \multicolumn{2}{|c|}{ e.Delete data rumah tangga } \\
\hline Data masukan & Nomor Kemisknan yang salah \\
\hline Yang diharapkan & Tidak menampilkan data rumah tangga yang dapat dihapus \\
\hline Pengamatan & Data tidak ditemukan \\
\hline Kesimpulan & {$[\checkmark]$ Diterima [ ] Ditolak } \\
\hline
\end{tabular}

Tabel 5. Pengujian indikator kemiskinan

\begin{tabular}{ll}
\hline \multicolumn{1}{c}{ Kasus dan Hasil Ujicoba (Data Benar) } \\
\hline a. Input data indikator kemiskinan \\
\hline Data masukan & Memasukan data indikator kemiskinan sesuai dengan field yang ada \\
\hline Yang diharapkan & $\begin{array}{l}\text { Proses memasukan data indikator kemiskinan selesai, melakukan klik button } \\
\text { simpan data, data tersimpan pada database dan menampilkan pesan data berhasil } \\
\text { disimpan }\end{array}$ \\
\hline Pengamatan & $\begin{array}{l}\text { Data indikator dapat tersimpan ke database dan menampilkan pesan data berhasil } \\
\text { disimpan }\end{array}$ \\
\hline Kesimpulan & {$[\checkmark$ ] Diterima [ ] Ditolak } \\
\hline \multicolumn{2}{l}{ bdit data indikator kemiskinan } \\
\hline Data masukan & Memasukan tahun indikator kemiskinan \\
\hline
\end{tabular}




\begin{tabular}{|c|c|}
\hline Yang diharapkan & $\begin{array}{l}\text { Menampilkan indikator kemiskian berdasarkan tahun, dapat mengklik link edit dan } \\
\text { menampilkan data pada form edit, dapat melakukan perubahan data, kemudian klik } \\
\text { button simpan data dan menampilkan pesan proes perubahan data berhasil } \\
\text { dilakukan }\end{array}$ \\
\hline Pengamatan & $\begin{array}{l}\text { Dapat menampilkan indikator kemiskian berdasarkan tahun, proses edit berhasil } \\
\text { dilakukan, dan menampilkan pesan edit berhasil dilakukan }\end{array}$ \\
\hline Kesimpulan & {$[\checkmark]$ Diterima [ ] Ditolak } \\
\hline \multicolumn{2}{|c|}{ c. Delete data indikator kemiskinan } \\
\hline Data masukan & Memasukan tahun indikator kemiskinan \\
\hline Yang diharapkan & $\begin{array}{l}\text { Menampilkan data indikator kemiskinan, dapat melakukan link delete data dan } \\
\text { menampilkan data berhasil di delete }\end{array}$ \\
\hline Pengamatan & $\begin{array}{l}\text { Dapat menampilkan data indikator kemiskinan dan menampilkan pesan pesan data } \\
\text { berhasil di-delete }\end{array}$ \\
\hline Kesimpulan & {$[\checkmark]$ Diterima [ ] Ditolak } \\
\hline \multicolumn{2}{|r|}{ Kasus dan Hasil Ujicoba (Data Salah) } \\
\hline \multicolumn{2}{|c|}{ a.Input data indikator kemiskinan } \\
\hline Data masukan & Memasukan tahun indikator kemiskinan yang salah \\
\hline Yang diharapkan & Menampilkan pesan kesalahan data tidak ditemukan \\
\hline Pengamatan & Dapat menampilkan pesan kesalahan data tidak ditemukan \\
\hline Kesimpulan & {$[\checkmark]$ Diterima [ ] Ditolak } \\
\hline \multicolumn{2}{|c|}{ b.Edit data indikator kemiskinan } \\
\hline Data masukan & Memasukan tahun indikator kemiskinan yang salah \\
\hline Yang diharapkan & Menampilkan pesan kesalahan data tidak ditemukan \\
\hline Pengamatan & Dapat menampilkan pesan kesalahan data tidak ditemukan \\
\hline Kesimpulan & {$[\checkmark]$ Diterima [ ] Ditolak } \\
\hline \multicolumn{2}{|c|}{ c. Delete data indikator kemiskinan } \\
\hline Data masukan & Memasukan tahun indikator kemiskinan yang salah \\
\hline Yang diharapkan & Menampilkan pesan kesalahan data tidak ditemukan \\
\hline Pengamatan & Dapat menampilkan pesan kesalahan data tidak ditemukan \\
\hline Kesimpulan & {$[\checkmark]$ Diterima [ ] Ditolak } \\
\hline
\end{tabular}

Tabel 6. Pengujian keterangan pokok

\begin{tabular}{ll}
\hline \multicolumn{1}{c}{ Kasus dan Hasil Ujicoba (Data Bernar) } \\
\hline a. Input data keterangan pokok \\
\hline Data masukan & Memasukkan data keterangan pokok sesuai dengan field \\
\hline Yang diharapkan & $\begin{array}{l}\text { Proses memasukan data keterangan pokok selesai, melakukan klik button simpan } \\
\text { data, data tersimpan pada database dan menampilkan pesan data berhasil disimpan }\end{array}$ \\
\hline Pengamatan & $\begin{array}{l}\text { Data keteragnan pokok dapat tersimpan ke database dan menampilkan pesan data } \\
\text { berhasil disimpan }\end{array}$ \\
\hline Kesimpulan & {$[\checkmark$ ] Diterima [ ] Ditolak } \\
\hline b. Edit data keterangan pokok \\
\hline Data masukan & Memasukan nomor kesmiskinan \\
\hline Yang diharapkan & $\begin{array}{l}\text { Menampilkan data keterangan pokok berdasarkan nomor kemiskinan, dapat klik } \\
\text { link edit, proses } \text { edit dilakukan dan kemudian menampilkan pesan edit berhasil } \\
\text { dilakukan }\end{array}$ \\
\hline Pengamatan & $\begin{array}{l}\text { Dapat menampilkan data keterangan pokok berdasarkan nomor kemiskinan, proses } \\
\text { edit berhasil dilakukan dan menampilkan pesan } \text { edit berhasil dilakukan }\end{array}$ \\
\hline Kesimpulan & {$[\checkmark$ ] Diterima [ ] Ditolak } \\
\hline c. Delete data keterangan pokok \\
\hline Data masukan & Memasukan nomor kesmiskinan \\
\hline Yang diharapkan & Menampilkan pesan kesalahan data indikator kemiskinan telah ada \\
\hline Pengamatan & Dapat menampilkan pesan kesalahan data indikator telah ada \\
\hline Kesimpulan & {$[\checkmark$ ] Diterima [ ] Ditolak } \\
\hline \multicolumn{1}{c}{ Kasus dan Hasil Ujicoba (Data Salah) } \\
\hline a.Input data keterangan pokok \\
\hline Data masukan & Memasukan data keterangan pokok dengan nomor kemiskinan yang sama \\
\hline Yang diharapkan & Menampilkan pesan kesalahan data telah ada \\
\hline Pengamatan & Dapat menampilkan pesan kesalahan data telah ada \\
\hline
\end{tabular}


Ependi, Implementasi dan Pengujian Antarmuka Sistem Informasi Penanggulangan Kemiskinan..

\begin{tabular}{|c|c|}
\hline Kesimpulan & {$[\sqrt{\checkmark}]$ Diterima [ } \\
\hline \multicolumn{2}{|c|}{ b.Edit data keterangan pokok } \\
\hline Data masukan & Memas \\
\hline Yang diharapkan & \\
\hline Pengamatan & Dapat $n$ \\
\hline Kesimpulan & {$[\sqrt{ }]$ Diterim } \\
\hline \multicolumn{2}{|c|}{ c.Delete data keterangan pokok } \\
\hline Data masukan & Memasuka \\
\hline Yang diharapkan & Menam \\
\hline Pengamatan & Dapat $\mathrm{r}$ \\
\hline Kesimpulan & {$[\checkmark]$ Diterima [ ] D } \\
\hline \multicolumn{2}{|c|}{$\begin{array}{l}\text { Dari pengujian alpha yang telah dilakukan } \\
\text { menggunakan data ujicoba dapat dikatakan } \\
\text { bahwa sistem informasi penanggulangan } \\
\text { kemiskinan (Simpeke) Kabupaten Ogan } \\
\text { Komering Ilir secara fungsional telah berjalan } \\
\text { dengan baik. Hal tersebut ditunjukan oleh hasil } \\
\text { pengujian yang menghasilkan kesimpulan }\end{array}$} \\
\hline
\end{tabular}

\subsection{Hasil Pengujian Beta}

Setelah melakukan pengujian alpha maka selanjutnya adalah melakukan pengujian beta. Pengujian beta dilakukan guna mendapatkan evaluasi dari sistem informasi penanggulangan kemiskinan (Simpeke) Kabupaten Ogan Komering Ilir yang diimplementasikan. apakah telah layak dan sesuai dengan kebutuhan pengguna akhir dari Simpeke. Pengujian beta ini dilakukan dengan cara memberikan kuesioner kepada pengguna akhir Simpeke dengan jumlah penyataan sebanyak 10 pernyataan. Dari hasil kuesioner yang diberikan kepada pengguna akhir yang terdiri dua puluh tujuh (27) responden dari unsur pimpinan, pegawai dan operator Simpeke mendapatkan respon masing-masing pernyataan sebagai berikut:

1. Sistem informasi penanggulangan kemiskinan (Simpeke) yang diimplementasi sesuai dengan fungsinya.

Tabel 7 Hasil pengujian beta pernyataan 1

\begin{tabular}{lcc}
\hline \multicolumn{1}{c}{ Jawaban } & Responden & Persentase \\
\hline $\begin{array}{l}\text { Sangat tidak } \\
\text { setuju }\end{array}$ & 0 & $0 \%$ \\
\hline Tidak setuju & 0 & $0 \%$ \\
\hline Cukup setuju & 6 & $22 \%$ \\
\hline Setuju & 8 & $30 \%$ \\
\hline Sangat setuju & 13 & $48 \%$ \\
\hline
\end{tabular}

2. Proses transfers, input, edit dan delete data pada sistem informasi dapat melakukan validasi dengan baik.

\begin{tabular}{lcc}
\multicolumn{3}{l}{ Tabel 8 Hasil pengujian beta pernyataan 2} \\
\hline \multicolumn{1}{c}{ Jawaban } & Responden & Persentase \\
\hline $\begin{array}{l}\text { Sangat tidak } \\
\text { setuju }\end{array}$ & 0 & $0 \%$ \\
\hline Tidak setuju & 0 & $0 \%$ \\
\hline Cukup setuju & 6 & $22 \%$ \\
\hline Setuju & 9 & $33 \%$ \\
\hline Sangat setuju & 12 & $45 \%$ \\
\hline
\end{tabular}

3. Sistem informasi penanggulangan kemiskinan (Simpeke) yang diimplementasi dapat membantu mengurai penumpukan data.

Tabel 9 Hasil pengujian beta pernyataan 3

\begin{tabular}{lcc}
\hline \multicolumn{1}{c}{ Jawaban } & Responden & Persentase \\
\hline $\begin{array}{l}\text { Sangat tidak } \\
\text { setuju }\end{array}$ & 0 & $0 \%$ \\
\hline Tidak setuju & 0 & $0 \%$ \\
\hline Cukup setuju & 4 & $15 \%$ \\
\hline Setuju & 10 & $37 \%$ \\
\hline Sangat setuju & 13 & $48 \%$ \\
\hline
\end{tabular}

4. Proses pengolahan data penduduk miskin menjadi lebih cepat.

Tabel 10 Hasil pengujian beta pernyataan 4

\begin{tabular}{lcc}
\hline \multicolumn{1}{c}{ Jawaban } & Responden & Persentase \\
\hline $\begin{array}{l}\text { Sangat tidak } \\
\text { setuju }\end{array}$ & 0 & $0 \%$ \\
\hline Tidak setuju & 0 & $0 \%$ \\
\hline Cukup setuju & 4 & $15 \%$ \\
\hline Setuju & 16 & $59 \%$ \\
\hline Sangat setuju & 7 & $26 \%$ \\
\hline
\end{tabular}

5. Sistem informasi penanggulangan kemiskinan (Simpeke) yang diimplementasi dapat melihat laporan penduduk dengan cepat.

Tabel 11 Hasil pengujian beta pernyataan 5

\begin{tabular}{lcc}
\hline \multicolumn{1}{c}{ Jawaban } & Responden & Persentase \\
\hline $\begin{array}{l}\text { Sangat tidak } \\
\text { setuju }\end{array}$ & 0 & $0 \%$ \\
\hline Tidak setuju & 0 & $0 \%$ \\
\hline Cukup setuju & 1 & $4 \%$ \\
\hline Setuju & 12 & $44 \%$ \\
\hline Sangat setuju & 14 & $52 \%$ \\
\hline
\end{tabular}


6. Sistem informasi penanggulangan kemiskinan (Simpeke) yang diimplementasi dapat menanggulangi manipulasi data.

Tabel 12 Hasil pengujian beta pernyataan 6

\begin{tabular}{lcc}
\hline \multicolumn{1}{c}{ Jawaban } & Responden & Persentase \\
\hline $\begin{array}{l}\text { Sangat tidak } \\
\text { setuju }\end{array}$ & 0 & $0 \%$ \\
\hline Tidak setuju & 0 & $0 \%$ \\
\hline Cukup setuju & 1 & $4 \%$ \\
\hline Setuju & 12 & $44 \%$ \\
\hline Sangat setuju & 14 & $52 \%$ \\
\hline
\end{tabular}

7. Sistem informasi penanggulangan kemiskinan (Simpeke) yang diimplementasi mudah untuk digunakan.

Tabel 13 Hasil pengujian beta pernyataan 7

\begin{tabular}{lcc}
\hline \multicolumn{1}{c}{ Jawaban } & Responden & Persentase \\
\hline $\begin{array}{l}\text { Sangat tidak } \\
\text { setuju }\end{array}$ & 0 & $0 \%$ \\
\hline Tidak setuju & 0 & $0 \%$ \\
\hline Cukup setuju & 2 & $7 \%$ \\
\hline Setuju & 10 & $37 \%$ \\
\hline Sangat setuju & 15 & $56 \%$ \\
\hline
\end{tabular}

8. Sistem informasi penanggulangan kemiskinan (Simpeke) yang diimplementasi dapat memberikan laporan mudah untuk dipahami.

Tabel 14 Hasil pengujian beta pernyataan 8

\begin{tabular}{lcc}
\hline \multicolumn{1}{c}{ Jawaban } & Responden & Persentase \\
\hline $\begin{array}{l}\text { Sangat tidak } \\
\text { setuju }\end{array}$ & 0 & $0 \%$ \\
\hline Tidak setuju & 0 & $0 \%$ \\
\hline Cukup setuju & 0 & $0 \%$ \\
\hline Setuju & 10 & $37 \%$ \\
\hline Sangat setuju & 17 & $63 \%$ \\
\hline
\end{tabular}

9. Sistem informasi penanggulangan kemiskinan (Simpeke) yang diimplementasi memberikan informasi penduduk secara detail.

Tabel 15 Hasil pengujian beta pernyataan 9

\begin{tabular}{lcc}
\hline \multicolumn{1}{c}{ Jawaban } & Responden & Persentase \\
\hline $\begin{array}{l}\text { Sangat tidak } \\
\text { setuju }\end{array}$ & 0 & $0 \%$ \\
\hline Tidak setuju & 0 & $0 \%$ \\
\hline Cukup setuju & 2 & $8 \%$ \\
\hline Setuju & 9 & $33 \%$ \\
\hline Sangat setuju & 16 & $59 \%$ \\
\hline
\end{tabular}

10. Sistem informasi penanggulangan kemiskinan (Simpeke) yang diimplementasi memberikan data yang akurat.

Tabel 16 Hasil pengujian beta pernyataan 10

\begin{tabular}{lcc}
\hline \multicolumn{1}{c}{ Jawaban } & Responden & Persentase \\
\hline $\begin{array}{l}\text { Sangat tidak } \\
\text { setuju }\end{array}$ & 0 & $0 \%$ \\
\hline Tidak setuju & 0 & $0 \%$ \\
\hline Cukup setuju & 2 & $7 \%$ \\
\hline
\end{tabular}

\begin{tabular}{lll}
\hline Setuju & 10 & $37 \%$ \\
\hline Sangat setuju & 15 & $56 \%$ \\
\hline
\end{tabular}

Berdasarkan hasil pengujian beta maka dapat disimpulkan evaluasi dari implementasi sistem informasi penanggulangan kemiskinan (Simpeke) Kabupaten Ogan Komering Ilir tersebut terlihat pada tabel 16 berikut ini.

Tabel 17 Kesimpulan pengujian beta

\begin{tabular}{lc}
\hline \multicolumn{1}{c}{ Jawaban } & Persentase \\
\hline Sangat tidak setuju & $0 \%$ \\
\hline Tidak setuju & $0 \%$ \\
\hline Cukup setuju & $10 \%$ \\
\hline Setuju & $39 \%$ \\
\hline Sangat setuju & $51 \%$ \\
\hline
\end{tabular}

Dari pengujian beta tersebut dapat dilihat bahwa responden menyatakan $51 \%$ sangat setuju dengan implementasi sistem informasi penanggulangan kemiskinan (Simpeke) Kabupaten Ogan Komering Ilir. Itu menunjukkan bahwa Simpeke yang diimplementasikan dapat meberikan data atau informasi yang dibutuhkan untuk mendukung dalam membuat kebijakan pengentasan kemiskinan pada Kabupaten Ogan Komering Ilir.

\section{SIMPULAN dan SARAN}

Berdasarkan latar belakang, pembahasan dan pengujian yang telah dilakukan terhadap sistem informasi penanggulangan kemiskinan (Simpeke) Kabupaten Ogan Komering Ilir maka dapat diambil kesimpulan sebagai berikut:

1. Sistem informasi penanggulangan kemiskinan (Simpeke) Kabupaten Ogan Komering Ilir secara keseluruhan berfungsi dengan baik hal tersebut ditunjukkan pada saat melakukan pengujian alpha.

2. Sistem informasi penanggulangan kemiskinan (Simpeke) Kabupaten Ogan Komering Ilir telah sesuai dengan prosedur. Hal tersebut ditunjukkan oleh jawaban responden yang rata-rata menjawab setuju dang sangat setuju.

3. Sistem informasi penanggulangan kemiskinan (Simpeke) Kabupaten Ogan Komering Ilir dapat memberikan data atau informasi secara detail yang berkaitan dengan predikat penduduk miskin sehingga dapat membantu pemerintah Kabupaten Ogan Komering Ilir dalam menentukan arah kebijakan pengentasan kemiskinan.

Dari implementasi dan pengujian yang telah dilakukan terhadap sistem informasi penanggulangan kemiskinan (Simpeke) Kabupaten Ogan Komering Ilir maka saran yang dapat peneliti berikan adalah sebagai berikut: 
Ependi, Implementasi dan Pengujian Antarmuka Sistem Informasi Penanggulangan Kemiskinan..

1. Sistem informasi penanggulangan kemiskinan (Simpeke) Kabupaten Ogan Komering Ilir dapat ditempatkan pada server yang memiliki kapasitas besar. Hal tersebut dikarenakan data yang dikelolah oleh Simpeke cukup besar.

2. Menyediakan infrastruktur yang memadai untuk pengaksesan atau pengoperasian Sistem informasi penanggulangan kemiskinan (Simpeke) Kabupaten Ogan Komering Ilir.

3. Sistem informasi penanggulangan kemiskinan (Simpeke) Kabupaten Ogan Komering Ilir hendaknya selalu diupdate dengan data terbaru sehingga data yang ditampilkan akurat dan sesuai kebutuhan pemerintah Kabupaten Ogan Komering Ilir. Sehingga dalam pengambilan kebijakan tidak terjadi kesalahan atau tidak tepat pada sasaran.

\section{DAFTAR RUJUKAN}

Ependi, Usman, 2013. Pengembangan EMusrenbang Perencanaan Pembangunan Daerah. In: UPN "Veteran", Seminar Nasional Informatika 2013 (semnasIF 2013). Yogyakarta, 18 Mei 2013, UPN "Veteran": Yogyakarta.

Indrajit, Richardus Eko., 2001. Pengantar Konsep Dasar Manajemen Sistem Informasi dan Teknologi Informasi. Jakarta: Gramedia.

Rahadi, Dedi Rianto, 2010. Strategi Manajemen Resiko Dalam Pengembangan Sistem Informasi (Studi Kasus Sistem Penanggulangan Kemiskinan Provinsi Sumsel). In: Institut Teknologin Sepuluh November, Seminar Nasional Sistem Informasi Indonesia (Sesindo). Surabaya, 4 Desember 2010, Jurusan Sistem Informasi Fakultas Teknologi Informasi ITS: Surabaya.

Sugiyono, 2011. Metode Penelitian Kuantitatif kualitatif dan $R \& D$. Bandung: Alfabeta.

Sukmadinata, 2006. Metode Penelitian Pendidikan. Bandung: Rosdakarya. 